\title{
Third Ventricle Germinoma
}

National Cancer Institute

\section{Source}

National Cancer Institute. Third Ventricle Germinoma. NCI Thesaurus. Code C156040.

A germinoma that arises from the third ventricle. 